\title{
EFFICACY OF DIETARY MORINGA OLEIFERA LEAVES SUPPLEMENTATION ON PRODUCTIVITY, CARCASS TRAITS, HEMATO- BIOCHEMICAL PARAMETERS, ANTIOXIDANTS STATUS AND IMMUNE RESPONSE IN HEAT STRESSED GROWING RABBITS.
}

\author{
W.A. Khalil ${ }^{1}$, Rehab F.S.A. Ismail ${ }^{1}$ and I.T. El-Ratel ${ }^{2}$ \\ ${ }^{1}$ Department of Animal Production, Faculty of Agriculture, Mansoura University, Mansoura, Egypt \\ ${ }^{2}$ Department of Poultry Production, Faculty of Agriculture, Damietta University, Damietta, Egypt \\ * Author for correspondence: El-Ratel, I.T, E-mail: ibrahim.talat81@yahoo.com
}

(Received 8/10/2019, accepted 26/11/2019)

\section{SUMMARY}

\begin{abstract}
$\mathrm{T}$ his study was conducted to evaluate whether adding Moringa oleifera dry leaves powder (MODLP) as a natural anti-oxidants in the diet, has the potential to attenuate the negative effects of heat stress on growth performance, healthy status, anti-oxidant defense system and immunity of growing rabbits. Weaned NZW rabbits $(n=120)$ were divided into four groups fed basal diet with 0, 100, 200 and 300 $\mathrm{mg}$ MODLP/kg. Growth performance parameters were recorded at age intervals from 5-13 wk. Caecal activity, carcass traits, hematological, serum biochemicals, antioxidant and immunity were determined at 13 wk of age. Results show that dietary addition of $200 \mathrm{mg}$ MODLP/kg increased $(\mathrm{P}<0.05)$ pulse rate, growth performance parameters, net carcass weight, dressing rate and spleen percentages, beneficial bacteria (lactobacillus) count, hematological parameters, serum high-density lipoproteins, total antioxidant capacity, antibody titer and lysozyme. Abdominal fat percentage, E. coli count, and total cholesterol, triglycerides and low-density lipoproteins and thiobarbituric acid-reactive substances concentration reduced $(\mathrm{P}<0.05) 200$ $\mathrm{mg} / \mathrm{kg}$ group. The current study indicated that alleviation of adverse impacts due to heat stress on productivity, blood constituents, oxidative stress and immunity status, can be achieved in growing rabbits through dietary adding Moringa Oleifera dried leaves at a level of $200 \mathrm{mg} / \mathrm{kg}$ diet.
\end{abstract}

Keywords: Moringa oleifera, rabbits, heat Stress, productivity, antioxidative status, immunity.

\section{INTRODUCTION}

The productive performance of growing rabbits is markedly affected climatic conditions (El-Gindy et. 2017). Exposure of rabbits to high temperature $\left(\geq 30^{\circ} \mathrm{C}\right)$ induces severe heat stress (Okab et al. 2008), leasing to high cost for rabbit farmers, due decreasing to rabbit production of meat (Villalobos et al. 2008). Core body temperature, in term of rectal temperature (RT) is a good indicator for the animal response to fluctuations in air temperature (Marai et al. 2002). During exposure of Broiler chicks to heat stress, lipid oxidant increased following increasing the generation of free radicals, which elevates reactive oxygen species (ROS) formation and cellular oxidative stress induction ( Hassan et al. 2016).

There are several natural plant anti-oxidants containing vitamin $\mathrm{C}$, tocopherols, flavonoids and other phenolic compounds ( Hassan et al. 2016). These compounds are important in elimination of heat stress impacts. Usage of these anti-oxidants in rabbit production are commercially accepted as strategy to improve the rabbit productive performance and health status (Ojo and Adetoyi, 2017). Moringa oleifera (MO) plant with their different parts in tropical and subtropical countries is with highly valued plant (Khalil and Korni, 2017). Phytochemical analyses of MO are rich in vitamins (C and B), carotene ( $\alpha$ and $\beta)$, minerals ( $\mathrm{Ca}, \mathrm{K}, \mathrm{Se}, \mathrm{Zn}, \mathrm{P}$ and $\mathrm{Fe}$ ), and essential amino acids (methionine and cysteine), polyphenols, 


\section{Khalil et al}

xanthins, and chlorophyll, and other phytochemicals with powerful anti-oxidant ability (Surai, 2002; Okwari et al., 2013). Therefore, MO leaves have ability to affect oxidative damage in animals by increasing anti-oxidant enzymes activity, decreasing lipid peroxidation, free radicals generation, and suppression of ROS formation (Osman et al., 2012), consequently improving meat quality (Giannenas et al., 2010). The MO leaves has properties as anti-tumor, antinflammatory, anti-oxidant, anti-ulcerous, antihyperlipidaemic and cholesterol lowering, anti-diabetic, anti-cancereous (Paul et al., 2018), anti-fungal and anti-bacterial (Bukar et al., 2010), which include 4-("-L-rhamnopyranosyloxy) benzyl isothiocyanate, Niazimicin, Pterygospermin, Benzyl isothiocyanate, 4-("-Lrhamnopyranosyloxy) and Benzyl glucosinolate (El-Kholy et al., 2018a).

Blood constituents reflected the animal physiology and health status under feeding trials and considered as an appropriate measures of the animal nutritional status (Terzungwe et al., 2013). Leaves of MO were found to effect on the haematological parameters and lipid profiles in animal blood (Serem et al., 2017). Additionally, rich nutrient profile of MO give this plant as a potential growth promoter and immunomodulatory effects (Paul et al., 2018). There are many attempts to use MO meal as a dietary inclusion in rabbit diets. However, usage of MO leaves as an anti-oxidant and anti-bacterial during growing stage in rabbits is rare. Therefore, this study aims to investigate the effects of Moringa oleifera leaves at levels of $0,100,200$ and $300 \mathrm{mg} / \mathrm{kg}$ diet, as natural anti-oxidants and anti-biotics, on physiological response, growth performance parameters, caecal activity, liver and kidney functions, antioxidant status, immune response and carcass quality of NZW growing rabbits reared under heat stress condition.

\section{MATERIALS AND METHODS}

The present study was carried out at Experimental Rabbitary Farm, and Physiology and Biotechnology Laboratory, Animal Production Department, Faculty of Agriculture, Mansoura University, Egypt, during the period from August 2018 to October 2018. All procedures were approved by the Animal Care and Welfare Committee of the Institute.

Packaged Moringa oleifera dry leaves powder (MODLP) used for this study was purchased from the Moringa plantation unit of the Scientific Association of Moringa, National Research Center, Dokki, Egypt.

\section{Environmental conditions}

Indoor ambient temperature (AT) and relative humidity (RH \%) were weekly recorded inside the rabbitry using electronic digital thermo-hygrometer. Average of maximum and minimum values of AT, RH and calculated thermal-humidity index (THI) during the experimental period are shown in Table 1. The THI was calculated according to the equation of Marai et al. (2001) as following:

$\mathrm{THI}=\mathrm{db}^{\circ} \mathrm{C}-\left[(0.31-0.31 \times \mathrm{RH}) \times\left(\mathrm{db}^{\circ} \mathrm{C}-14.4\right)\right]$.

Where $\mathrm{db}{ }^{\circ} \mathrm{C}=$ dry bulb temperature.

Values of THI $<27.8=$ absence of heat stress; 27.8 to $28.8=$ moderate heat stress; 28.9 to $29.9=$ severe heat stress, while $>30.0=$ very severe heat stress.

Table (1): Overall means of ambient temperature, relative humidity and thermal-humidity index (THI) during the experimental period.

\begin{tabular}{lcc}
\hline Item & Minimum & Maximum \\
\hline Ambient temperature $\left({ }^{\circ} \mathrm{C}\right)$ & $25.17 \pm 0.98$ & $33.61 \pm 1.00$ \\
Relative humidity $(\%)$ & $44.67 \pm 7.57$ & $82.83 \pm 2.78$ \\
THI value & $23.33 \pm 0.91$ & $32.59 \pm 1.08$ \\
\hline
\end{tabular}

\section{Experimentalanimals andmanagement}

Total of 120 male New Zealand white rabbits weaned at 5 weeks of age and averaged $688.5 \pm 2.135 \mathrm{~g}$ initial body weight were disturbed according to body weight into four experimental groups ( $\mathrm{n}=30$ in each) were used in this study. Rabbits were individually housed in galvanized wire cages $(35 \times 35 \times 60 \mathrm{~cm})$ under similar hygienic conditions. Feed and clean water were offered ad libitum until 13 weeks of age. 
Rabbits in the $1^{\text {st }}$ group (G1) were fed a commercial pelleted diet without any supplementation (control diet), while 100, 200 and $300 \mathrm{mg}$ of MODLP were added to the control diet of rabbits in the $2^{\text {nd }}$ $(\mathrm{G} 2), 3^{\text {rd }}(\mathrm{G} 3)$ and $4^{\text {th }}(\mathrm{G} 4)$ group, respectively. The control diet was formulated to cover all essential nutrient requirements of growing rabbits according to NRC (1977) as shown in Table 2. Chemical composition of the control diet and MODLP, on dry matter basis, according to the standard methods of AOAC (2012) is presented in Table 3.

Table (2): Ingredients of the control diet used for feeding rabbits in the experimental groups.

\begin{tabular}{|c|c|c|c|}
\hline Ingredient & $(\%)$ & Ingredient & $(\%)$ \\
\hline Berseem hay & 30.05 & Di-calcium phosphate & 1.60 \\
\hline Barley grain & 24.60 & Limestone & 0.95 \\
\hline Wheat brain & 21.50 & DL-Methionine & 0.20 \\
\hline Soybean meal (44\%) & 17.50 & Sodium chloride & 0.30 \\
\hline Molasses & 3.00 & Premix $^{1}$ & 0.30 \\
\hline
\end{tabular}

Table (3): Chemical composition of the control diet and Moringa oleifera dry leaves.

\begin{tabular}{lcc}
\hline Chemical composition $(\%)$ & Control diet & Moringa oleifera dry leaves \\
\hline Organic matter & 91.42 & 89.55 \\
Crude protein & 17.36 & 19.70 \\
Crude fiber & 12.37 & 8.20 \\
Ether extract & 2.23 & 6.30 \\
Nitrogen free extract & 59.46 & 55.35 \\
Ash & 8.58 & 10.45 \\
\hline
\end{tabular}

\section{Analytical procedures for Moringa oleifera dry leaves}

Anti-oxidant capacity of MODLP in terms of contents of vitamin A and C (Achikanu et al. 2013), alkaloids (Harborne, 1973), total phenolic (McDonald et al., 2001) and flavonoids (Kumaran and Karunakaran, 2007) in MODLP were determined. Also, activity of superoxide dismutase and catalase and glutathione concentration was determined using the method described by Malliga et al. (2014) as shown in Table 4. These analyzed for their active components of MODLP at Regional Centre for Food and Feed, RCFF, Agricultural Research Center, Ministry of Agriculture, Giza, Egypt.

Table (4): Vitamin content, bioactive anti-oxidant compounds and phytochemical composition of Moringa Oleifera dry leaves.

\begin{tabular}{lc}
\hline Item & Concentration \\
\hline Vitamin content $(\mathrm{mg} / 100 \mathrm{~g}):$ & \\
Vitamin E & 0.37 \\
Vitamin C & 0.25 \\
Anti-oxidant activity & 25.80 \\
Glutathione (nmoles/g) & 12.20 \\
Superoxide dismutase (U/g) & 95.00 \\
Catalase (U/g) & \\
Phytochemical composition & 4.50 \\
Total flavonoids (mg/g) & 2.50 \\
Total polyphenols $\%)$ & 350 \\
Alkaloids (mg/100g) & \\
\hline
\end{tabular}




\section{Khalil et al}

\section{Experimental procedures}

\section{Physiological response}

Rectal temperature $(\mathrm{RT})$, respiration rate $(\mathrm{RR})$ and pulse rate $(\mathrm{PR})$ were recorded daily for $7 \mathrm{~d}$ in the morning (7 a.m.) before feeding during the last week of the experimental period (13 wk of age). The RT was measured to the nearest $0.1^{0} \mathrm{C}$ by clinical thermometer into the rectum. While RR was measured by counting the flank movements for one min and PR was measured by femoral vein for one min.

\section{Growth performance parameters}

During the experimental period, live body weight (LBW) and daily feed intake (DFI) were weekly recorded, then average daily weight gain (ADG) and feed conversion ratio (FCR) were calculated at age intervals of 5-9, 9-13 and 5-13 wk. Also, dead rabbits were recorded, and then viability rate (VR) was computed and performance index (PI) was calculated during the entire length of the experimental period (5-13 wk). Performance index was calculated according to the following equation: $P I=($ Final LBW $(\mathrm{kg}) / F C R) \times 100$.

\section{Blood sampling}

Blood samples were collected at the end of the experimental period (13 wk of age), from five rabbits in each group during slaughter, into two test tubes for each animal, one with anticoagulant for haematological parameters and another test tube without anticoagulant for biochemical parameters in blood serum.

Haematological parameters, including hemoglobin $(\mathrm{Hb})$ concentration, hematocrit value (Ht), count of red (RBCs), white (WBCs) blood cells and platelets were determined according to Provan et al. (2004).

The collected blood samples in tube without anticoagulant were centrifuged at $3500 \mathrm{rpm}$ for $15 \mathrm{~min}$ to separate blood serum, which was stored at $-20^{\circ} \mathrm{C}$ till assayed.

Concentration of total proteins (TP), albumin (AL), cholesterol, triglycerides, high density lipoproteins (HDL), low density lipoproteins (LDL), creatinine and urea as well as activity of aspartate (AST) and alanine (ALT) transaminases were determined in blood serum using commercial kits (BioMerieux, Laboratory Reagents and Products, France). Globulin concentration was obtained by difference between TP and AL concentration.

Anti-oxidants status, including total anti-oxidant capacity (TAC) and thiobarbituric acid-reactive substances (TBARS) were assayed in blood serum using commercially available kits (Bio Diagnostic Research).

\section{Antibody titer}

On day 15 after starting the experimental period, other five rabbits chosen from each group were immunized with $0.1 \mathrm{ml}$ of a $2.5 \%$ Sheep Red Blood Cells (SRBCs) to measure antibody titer against SRBCs. Antiserum to SRBCs was collected 7 days post-challenge according to Wegmann and Smithies (1966). The agglutination titer was expressed as the $\log _{2}$ (Nelson et al., 1995). Also, Lysozyme activity was determined according to Schultz (1987).

\section{Caecal activity}

The caecal contents were immediately taken from the slaughtered rabbits from each group, and filtrated to estimate $\mathrm{pH}$ by digital $\mathrm{pH}$ meter, and then the caecal content was divided into two samples, one for estimation the total anaerobic bacteria count and Escherichia coli (E. coli) according to according to Collins et al. (1995), and lactobacilli bacteria count according to Kim and Goepfert (1971). Another sample was filtered through four folds of gauze for determination of total volatile fatty acids (TVFA) and ammonia nitrogen by steam distillation according to Warner (1964).

\section{Carcass traits}

The slaughtered rabbits $(\mathrm{n}=5)$ were fasted for $12 \mathrm{~h}$ and individually weighed to estimate pre-slaughter weight. Then, carcass traits were recorded. Carcass parts and body internal organs were weighed and calculated as percentage relative to LBW of each animal. Meat samples were taken from the trunk of each rabbit and minced, then dried at $60^{\circ} \mathrm{C}$ for $48 \mathrm{~h}$ and grounded for approximate chemical analysis according to AOAC (2012). 


\section{Statistical Analysis}

All data was statistically analyzed by one-way ANOVA design using a software package (SAS, 2002). Completely randomized design was used based on the following model: $Y_{i j}=\mu+G_{i}+e_{i j}$

Where $\mu=$ the overall mean, $G_{i}=$ group (1...4), and $\mathrm{e}_{\mathrm{ij}}=$ residual error.

Viability rate and carcass traits percentages were statistically analyzed using Chi-Square test. The percentage values were transformed by arcsine values before analysis. The group significant differences were tested by Duncan's multiple range test (Duncan, 1955) and set at $\mathrm{P}<0.05$.

\section{RESULTS AND DISCUSSION}

Physiological response: The recorded values of THI during the experimental period $(\mathrm{THI}=32.59)$ indicated that rabbits in all groups were kept under very severe heat stress (THI value $>30$ ) according to Marai et al. (2001). Rabbits exposed to high ambient temperature $\left(\geq 30{ }^{\circ} \mathrm{C}\right)$ are severing from heat stress, because rabbits have difficulty to eliminate body heat under long period due to the unfunctional sweat glands (Marai et al., 2002).

During the experimental period, the rectal temperature (RT) and respiratory rate (RR) values were not affected significantly $(\mathrm{P} \geq 0.05)$ by MODLP treatments under heat stress condition. On the other hand, pulse rate $(\mathrm{PR})$ was significantly $(\mathrm{P}<0.05)$ higher in G3 than in G1 (control), but did not differ significantly from that in G2 (Table 5).

In agreement with the present results, El-Gindy et al. (2017) showed that RT and RR of growing rabbits were not significantly affected by feeding different levels of MO leaf meal under heat stress. In goats, the PR was higher $(\mathrm{P}<0.05)$ in animals fed different levels of MO leaf meal than those fed the control diet (Babeker and Abdalbagi, 2015). It was reported that MO is of high and better nutritional value as signs of health and more productive animals (Addass et al., 2010). This increase may be attributed to increasing heat production as a results of more feed utilization in G3 than in other groups.

It is of interest to note that animals exposed to sever heat stress significantly increased thermoregulatory parameters, in terms rectum and skin temperatures (Marai et al., 2007). Generally, body temperature is affected by many factors like feed, environmental temperature, disease, sex and age (Guyton and Hall, 2000). The observed insignificant differences in RT and RR under heat stress may indicate no positive effect of MO addition on physiological response of rabbits in treatment groups.

Table (5): Effect of Moringa oleifera dry leaves powder on some physiological parameters.

\begin{tabular}{|c|c|c|c|c|c|c|}
\hline \multirow[b]{2}{*}{ Item } & \multirow[b]{2}{*}{$\begin{array}{c}\text { Control } \\
\text { (G1) }\end{array}$} & \multicolumn{3}{|c|}{ Moringa oleifera dry leaves powder level } & \multirow[b]{2}{*}{ SEM } & \multirow[b]{2}{*}{$\begin{array}{c}\mathrm{P}- \\
\text { value }\end{array}$} \\
\hline & & $\begin{array}{c}\mathrm{G} 2 \\
(100 \mathrm{mg} / \mathrm{kg} \\
\text { diet })\end{array}$ & $\begin{array}{c}\mathrm{G} 3 \\
(200 \mathrm{mg} / \mathrm{kg} \\
\text { diet })\end{array}$ & $\begin{array}{c}\mathrm{G} 4 \\
(300 \mathrm{mg} / \mathrm{kg} \\
\text { diet })\end{array}$ & & \\
\hline Rectal temperature $\left({ }^{\circ} \mathrm{C}\right)$ & 39.73 & 38.33 & 39.13 & 39.39 & 1.027 & 0.8253 \\
\hline Respiration rate (r/m) & 47.35 & 47.82 & 47.99 & 47.60 & 0.512 & 0.8296 \\
\hline Pulsed rate (pulse/min) & $72.80^{\mathrm{b}}$ & $75.86^{\mathrm{ab}}$ & $79.04^{\mathrm{a}}$ & $73.02^{\mathrm{b}}$ & 1.598 & 0.0453 \\
\hline
\end{tabular}

Growth performance: Addition of MODLP with different levels in the diets of all treatment groups (G2, G3 and G4) significantly ( $\mathrm{P}<0.05)$ increased LBW at 9 and $13 \mathrm{wk}$ of age, reflecting significantly $(\mathrm{P}<0.05)$ higher average daily gain (ADG) at 5-9, 9-13 and 5-13 wk of age intervals. Only at 9-13wk of age, daily feed intake (DFI) significantly $(\mathrm{P}<0.05)$ increased by increasing level of MODLP up to $200 \mathrm{mg} / \mathrm{kg} \mathrm{diet.}$ However, there were no significant differences in DFI at 5-9 and 5-13 of age intervals. All levels of MODLP significantly $(\mathrm{P}<0.05)$ improved the FCR compared with the control group at all age intervals. This finding was associated with ADG and DFI in each group. Rabbits in G3 showed the highest ADG and DFI, while those in G2 and G4 showed higher ADG and lower DFI as compared to the control group. The recorded improve in LBW and FCR of treatment groups reflected significant $(\mathrm{P}<0.05)$ increase in performance index (PI) in all treatment groups (G2, G3 and G4) as compared to the control group, being 


\section{Khalil et al}

significantly in G3 and G4. The highest PI and viability rate (VR) of rabbits in G3 indicated the superiority of G3 in growth performance parameters as compared to other groups (Table 6).

These results indicated beneficial effects of dietary addition of MODLP (200 mg/kg diet) on growth performance of growing rabbits. These findings are in the same line with the previous published reports on growing rabbits, fed graded levels of MO leaf meal in the diet (Abubakar et al. 2015), treated with MO leaf as a natural anti-oxidant (El-Gindy et al., 2017) or aqueous MO leaves extract (El-Kholy et al., 2018a) and MO supplementation (Aljohani and Abduljawad, 2018), who found that MO could play a good impact on growth performance of rabbits.

Table (6): Effect of Moringa oleifera dry leaves powder on growth performance of NZW growing rabbits at different age intervals.

\begin{tabular}{|c|c|c|c|c|c|c|}
\hline \multirow[b]{2}{*}{ Item } & \multirow[b]{2}{*}{$\begin{array}{c}\text { Control } \\
\text { (G1) }\end{array}$} & \multicolumn{3}{|c|}{ Moringa oleifera dry leaves powder level } & \multirow[b]{2}{*}{ SEM } & \multirow[b]{2}{*}{$\begin{array}{c}\mathrm{P}- \\
\text { value }\end{array}$} \\
\hline & & $\begin{array}{c}\mathrm{G} 2 \\
(100 \mathrm{mg} / \mathrm{kg} \\
\text { diet })\end{array}$ & $\begin{array}{c}\mathrm{G} 3 \\
(200 \mathrm{mg} / \mathrm{kg} \\
\text { diet })\end{array}$ & $\begin{array}{c}\mathrm{G} 4 \\
(300 \mathrm{mg} / \mathrm{kg} \\
\text { diet })\end{array}$ & & \\
\hline \multicolumn{7}{|c|}{ Average live body weight (g) } \\
\hline At 5 wk (Initial) & 688.93 & 684.67 & 689.66 & 690.87 & 2.135 & 0.8212 \\
\hline At 9 wk & $1372.78^{\mathrm{d}}$ & $1417.58^{c}$ & $1441.11^{\mathrm{a}}$ & $1436.52^{b}$ & 1.554 & 0.001 \\
\hline At 13 wk (Final) & $2076.96^{\mathrm{d}}$ & $2153.92^{c}$ & $2192.59^{\mathrm{a}}$ & $2179.32^{\mathrm{b}}$ & 1.807 & 0.001 \\
\hline \multicolumn{7}{|c|}{ Average daily gain $(\mathrm{g})$} \\
\hline At 5 9 wk & $24.42^{\mathrm{d}}$ & $26.17^{\mathrm{c}}$ & $26.82^{\mathrm{a}}$ & $26.59^{\mathrm{b}}$ & 0.029 & 0.001 \\
\hline At $9 \sim 13 \mathrm{wk}$ & $25.15^{\mathrm{d}}$ & $26.30^{\mathrm{c}}$ & $26.84^{\mathrm{a}}$ & $26.53^{\mathrm{b}}$ & 0.028 & 0.001 \\
\hline At $5 \sim 13 \mathrm{wk}$ & $24.79^{\mathrm{d}}$ & $26.23^{c}$ & $26.83^{\mathrm{a}}$ & $26.56^{\mathrm{b}}$ & 0.021 & 0.001 \\
\hline \multicolumn{7}{|c|}{ Average daily feed intake (g) } \\
\hline At 5 9 wk & 85.17 & 87.58 & 87.67 & 86.80 & 0.916 & 0.210 \\
\hline At 9 13wk & $123.63^{c}$ & $126.75^{\mathrm{ab}}$ & $128.85^{\mathrm{a}}$ & $125.64^{\mathrm{bc}}$ & 0.804 & 0.001 \\
\hline At $5 \sim 13 \mathrm{wk}$ & 95.29 & 96.17 & 97.04 & 95.15 & 0.733 & 0.226 \\
\hline \multicolumn{7}{|c|}{ Feed conversion ratio ( $\mathrm{g}$ feed/g gain) } \\
\hline At $5 \sim 9$ wk & $3.49^{\mathrm{a}}$ & $3.35^{\mathrm{b}}$ & $3.27^{\mathrm{b}}$ & $3.26^{\mathrm{b}}$ & 0.035 & 0.001 \\
\hline At $9 \sim 13 \mathrm{wk}$ & $3.78^{\mathrm{a}}$ & $3.66^{\mathrm{b}}$ & $3.61^{b}$ & $3.59^{\mathrm{b}}$ & 0.029 & 0.001 \\
\hline At $5 \sim 13 \mathrm{wk}$ & $3.84^{\mathrm{a}}$ & $3.67^{\mathrm{b}}$ & $3.62^{b}$ & $3.59^{\mathrm{b}}$ & 0.028 & 0.001 \\
\hline Performance & $54.17^{\mathrm{c}}$ & $58.84^{\mathrm{b}}$ & $60.70^{\mathrm{a}}$ & $60.58^{\mathrm{a}}$ & 0.460 & 0.001 \\
\hline
\end{tabular}

$(\%)$

Viability rate $(\%)$

$80 \quad 80$

$90 \quad 87$

${ }_{a, b, c \text { and } d}:$ Means in the same row with different superscripts are significantly different from each other $(P<0.05)$.

The yielded improvement of productive performance of growing rabbits may be attributed to that MO is rich in amino acids, vitamins and minerals (Faye et al., 2011) and the biological function of MO as a natural growth promoter (El-Badawi et al., 2014). Also, MO was used as anti-microbial agent (lipophilic compounds), which might improve nutrient utilization (Caceres et al., 1991). Moreover, phytochemical compounds (alkaloids, flavonoids and polyphenols) present in MO and anti-oxidant activity, may attach to the cytoplasmic membrane and remove free radicals, activate anti-oxidant enzymes and inhibit oxidases (Luqman et al., 2011).

Caecal activity: Results in Table 7 indicated significant $(\mathrm{P}<0.05)$ change of caecal activity in treated groups. Concentration of $\mathrm{NH}_{3}-\mathrm{N}$ and total volatile fatty acids (TVFA) significantly $(\mathrm{P}<0.05)$ reduced only in G3 and G4 compared with G1. This trend of reduction reflected lower $\mathrm{pH}$ value, but the differences were not significant.

The observed decrease in $\mathrm{NH}_{3}-\mathrm{N}$ and TVFA concentrations in $\mathrm{G} 3$ and $\mathrm{G} 4$ was in parallel with decreasing total count of bacteria causing by significant decrease in some harmful bacteria, particularly E. coli, but there was significant increase in beneficial bacteria count, such as lactobacillus. According to the previous findings, higher production of $\mathrm{NH}_{3}-\mathrm{N}$ and TVFA occurred with the caecum with high rate of absorption via caecal wall, leading to marked reduction in their concentrations in the caecal contents.

These results indicated beneficial impacts of dietary addition of MODLP on the microbial ecology of the gastrointestinal tract of growing rabbits. These results are in agreement with the results of El-Kholy et al. (2018a) and Aljohani and Abduljawad (2018). The phytogenic compounds of MO have positive effects, such as the gut microflora regulation and the immune-response stimulation (Aljohani and 
Abduljawad, 2018). The anti-microbial activity of MO may be attributed to the presence of bioactive compounds, inhibiting the microbial growth and interrupting some metabolic processes (Godstime et al., 2014). The present results indicated the anti-bacterial activity of MO on E. coli (Abalaka et al., 2012). Accordingly, MODLP could be a promising natural anti-microbial agent, beside the anti-oxidant activity (El-Kholy et al., 2018a).

Table (7): Effect of Moringa oleifera dry leaves powder on caecal activity of NZW growing rabbits.

\begin{tabular}{|c|c|c|c|c|c|c|}
\hline \multirow[b]{2}{*}{ Item } & \multirow[b]{2}{*}{$\begin{array}{c}\text { Control } \\
\text { (G1) }\end{array}$} & \multicolumn{3}{|c|}{ Moringa oleifera dry leaves powder level } & \multirow[b]{2}{*}{ SEM } & \multirow[b]{2}{*}{$\begin{array}{c}\text { P- } \\
\text { value }\end{array}$} \\
\hline & & $\begin{array}{c}\mathrm{G} 2 \\
(100 \mathrm{mg} / \mathrm{kg} \\
\text { diet })\end{array}$ & $\begin{array}{c}\mathrm{G} 3 \\
(200 \mathrm{mg} / \mathrm{kg} \\
\text { diet })\end{array}$ & $\begin{array}{c}\mathrm{G} 4 \\
(300 \mathrm{mg} / \mathrm{kg} \\
\text { diet })\end{array}$ & & \\
\hline $\mathrm{NH}_{3}-\mathrm{N}(\mathrm{mg} / \mathrm{dl})$ & $30.40^{\mathrm{a}}$ & $27.20^{\mathrm{ab}}$ & $23.40^{\mathrm{b}}$ & $24.80^{\mathrm{b}}$ & 1.255 & 0.010 \\
\hline $\begin{array}{l}\text { Total volatile fatty acids } \\
(\mathrm{meq} / \mathrm{dl})\end{array}$ & $6.71^{\mathrm{a}}$ & $6.77^{\mathrm{ab}}$ & $6.81^{\mathrm{c}}$ & $6.85^{\mathrm{b}}$ & 0.023 & 0.004 \\
\hline $\mathrm{pH}$ value & 5.94 & 5.93 & 5.89 & 5.92 & 0.015 & 0.173 \\
\hline Total bacterial count $\left(\times 10^{6}\right)$ & $21.60^{\mathrm{a}}$ & $19.80^{\mathrm{ab}}$ & $18.60^{\mathrm{c}}$ & $16.80^{\mathrm{b}}$ & 0.948 & 0.017 \\
\hline Lactobacilli count $\left(\mathrm{X} 10^{5}\right)$ & $6.25^{\mathrm{c}}$ & $7.48^{\mathrm{b}}$ & $8.96^{\mathrm{a}}$ & $7.05^{\mathrm{b}}$ & 0.164 & 0.001 \\
\hline Escherichia coli count $\left(\mathrm{X} 10^{4}\right)$ & $6.66^{\mathrm{a}}$ & $5.71^{\mathrm{b}}$ & $3.814^{\mathrm{d}}$ & $4.92^{\mathrm{c}}$ & 0.092 & 0.001 \\
\hline
\end{tabular}

Hematology, biochemicals and enzyme activity in blood serum: All hematological parameters (hemoglobin, RBCs, WBCs, platelets and hematocrit) significantly $(\mathrm{P}<0.05)$ improved by all levels of MODLP. Total cholesterol, triglycerides and low-density lipoproteins (LDL) concentrations in serum significantly $(\mathrm{P}<0.05)$ decreased in MODLP groups compared with control group, while HDL concentration was significantly $(\mathrm{P}<0.05)$ higher only in $\mathrm{G} 3$ than in other groups. On the other hand, the effect of MODLP treatment on serum total proteins (TP), albumin (AL), globulin (GL), creatinine and urea concentrations as well as on aspartate (AST) and alanine (ALT) transaminases activities was not significant (Table 8).

The present results indicated no adverse effects of dietary adding MODLP on protein metabolites (TP, AL and GL) kidney (creatinine and urea) and liver (AST and ALT) functions. However, MODLP treatment had positive and pronounced effects on hematological parameters and lipid profile, particularly at level of $200 \mathrm{mg} / \mathrm{kg}$ diet.

The assessment of hematological parameters could be used to reveal the deleterious effect of some chemicals in plant extracts (Oyedemi et al., 2011). The present improvement in all hematological parameters in G3 indicated that MODLP had positive influence on blood hematological parameters in growing rabbits under Egyptian conditions (El-Kholy et al., 2018b). The observed increase in RBCs, platelets and hematocrit value may be attributed to that MODLP is rich in amino acids, vitamins, minerals, particularly, iron and contain strong antioxidants (Morsy et al., 2007; Faye et al., 2011).

In consistent with the obtained results in the current study, similar results were reported by several authors regarding the hematological parameters of growing rabbits (El-Gindy et al., 2017; Ojo and Adetoyi 2017; El-Kholy et al., 2018b; Aljohani and Abduljawad 2018) or rats (Otitoju et al., 2014) treated with MO.

The marked reduction in lipid profile was reported by several authors on growing rabbits (Musa et al. 2014; Etchu et al., 2017; El-Kholy et al., 2018b). Concentration of LDL is a major component of the total cholesterol and considered as the main target of any lipid lowering agent (atherogenic lipoprotein) like MO leaves (El-Gindy et al., 2017). The MO contains bioactive components ( $\beta$-sitosterol and phytoconstituent), which exhibit hypocholesterolemic effect (Mbikay, 2012). Also, the hypolipidemia of MO may be due two mechanism actions by reducing cholesterol biosynthesis and absorption of dietary cholesterol (Hassarajani et al. 2007). On the other hand, the recorded insignificant effect of MO on protein metabolites is in good agreement with results reported on rabbits by Terzungwe et al. (2013). It is of interest to observe that enzyme activity in treatment groups is within a normal range, indicating intact muscle and organs like the liver and kidney of rabbits (Ewuola et al., 2015).

These results indicated that MODLP treatment had impact on hematology and lipid profile as well as normal protein metabolism and enzyme activity, reflecting good health status of growing rabbits. 
Table (8): Effect of Moringa oleifera dry leaves powder on haematology, serum biochemicals and enzyme activity in NZW growing rabbits.

\begin{tabular}{|c|c|c|c|c|c|c|}
\hline \multirow[b]{2}{*}{ Item } & \multirow[b]{2}{*}{$\begin{array}{c}\text { Control } \\
\text { (G1) }\end{array}$} & \multicolumn{3}{|c|}{ Moringa oleifera dry leaves powder level } & \multirow[b]{2}{*}{ SEM } & \multirow[b]{2}{*}{$\begin{array}{l}\mathrm{P}- \\
\text { value }\end{array}$} \\
\hline & & $\begin{array}{c}\mathrm{G} 2 \\
(100 \mathrm{mg} / \mathrm{kg} \\
\text { diet })\end{array}$ & $\begin{array}{c}\text { G3 } \\
(200 \mathrm{mg} / \mathrm{kg} \\
\text { diet })\end{array}$ & $\begin{array}{c}\mathrm{G} 4 \\
(300 \mathrm{mg} / \mathrm{kg} \\
\text { diet })\end{array}$ & & \\
\hline \multicolumn{7}{|l|}{ Hematological parameters: } \\
\hline Hemoglobin (mg/dl) & $9.53^{\mathrm{c}}$ & $9.79^{\mathrm{ab}}$ & $9.84^{\mathrm{a}}$ & $9.74^{\mathrm{b}}$ & 0.021 & 0.0001 \\
\hline $\operatorname{RBCs}\left(\times 10^{6} / \mathrm{mm}^{3}\right)$ & $5.44^{\mathrm{d}}$ & $5.89^{\mathrm{c}}$ & $6.28^{\mathrm{a}}$ & $6.04^{\mathrm{b}}$ & 0.034 & 0.0001 \\
\hline WBCs $\left(\mathrm{x} 10^{3} / \mathrm{mm}^{3}\right)$ & $6.55^{\mathrm{d}}$ & $6.91^{\mathrm{b}}$ & $7.07^{\mathrm{a}}$ & $6.76^{\mathrm{c}}$ & 0.025 & 0.0001 \\
\hline Platelets (x $\left.10^{3} / \mathrm{mm}^{3}\right)$ & $235.20^{\mathrm{c}}$ & $254.80^{\mathrm{a}}$ & $258.20^{\mathrm{a}}$ & $249.80^{\mathrm{b}}$ & 1.609 & 0.0001 \\
\hline Hematocrit $(\%)$ & $36.46^{\mathrm{c}}$ & $42.82^{\mathrm{b}}$ & $48.45^{\mathrm{a}}$ & $43.04^{\mathrm{b}}$ & 1.631 & 0.0010 \\
\hline \multicolumn{7}{|c|}{ Serum biochemicals (mg/dl): } \\
\hline Total proteins & 6.19 & 6.16 & 6.134 & 6.15 & 0.022 & 0.3473 \\
\hline Albumin & 3.99 & 3.95 & 3.92 & 3.94 & 0.029 & 0.4588 \\
\hline Globulin & 2.20 & 2.21 & 2.21 & 2.22 & 0.035 & 0.9943 \\
\hline Total cholesterol & $128.20^{\mathrm{a}}$ & $118.60^{\mathrm{b}}$ & $110.60^{c}$ & $120.20^{\mathrm{b}}$ & 1.643 & 0.0001 \\
\hline Triglycerides & $114.20^{\mathrm{a}}$ & $98.40^{\mathrm{b}}$ & $89.63^{c}$ & $101.21^{\mathrm{b}}$ & 1.871 & 0.0001 \\
\hline Low density lipoproteins & $56.44^{\mathrm{a}}$ & $51.06^{\mathrm{b}}$ & $42.20^{c}$ & $52.22^{\mathrm{b}}$ & 1.329 & 0.0001 \\
\hline $\begin{array}{l}\text { High density } \\
\text { lipoproteins }\end{array}$ & $58.66^{\mathrm{b}}$ & $65.20^{\mathrm{ab}}$ & $70.60^{\mathrm{a}}$ & $64.60^{\mathrm{ab}}$ & 2.724 & 0.0511 \\
\hline Creatinine & 1.50 & 1.46 & 1.43 & 1.44 & 0.097 & 0.9660 \\
\hline Urea & 39.80 & 39.50 & 39.20 & 39.60 & 1.369 & 0.9915 \\
\hline \multicolumn{7}{|l|}{ Enzyme activity (IU/l): } \\
\hline Aspartate transaminases & 33.80 & 33.64 & 33.24 & 33.42 & 1.094 & 0.9844 \\
\hline Alanine transaminases & 20.24 & 19.98 & 19.81 & 19.90 & 1.086 & 0.9928 \\
\hline
\end{tabular}

${ }_{a, b, c \text { and } d}$ :Means in the same row with different superscripts are significantly different from each other $(P<0.05)$.

Antioxidant and immunity: Treatment with MODLP at all levels significantly $(\mathrm{P}<0.05)$ increased total antioxidant capacity (TAC), while decreased thiobarbituric acid-reactive substances (TBARS) concentration in blood serum of growing rabbits, reflecting higher antioxidant defense system of treatment groups, in particular in G3. Also, MODLP treatment significantly $(\mathrm{P}<0.05)$ increased antibody titters against SRBCs and lysozyme concentration, representing higher immunity of treatment groups than the control one, being the highest $(\mathrm{P}<0.05)$ in $\mathrm{G} 3$ (Table 9).

Similarly, Ojo and Adetoyi (2017) and El-Kholy et al. (2018b) found that MO leaves treatment had beneficial effects on increasing TAC and reducing lipid peroxidation of growing rabbits. Also, in rats, Tuorkey (2016) showed that MO leaf extract administration decreased lipid peroxidation and increased TAC. These results may be attributable to the presence of flavonoids and polyphenols in MO leaves that can ameliorate oxidative stress (El-Kholy et al., 2018b). Also, MO leaves act as potentially antioxidant phyto-chemicals like caffeic and chlorogenic acids (Siddhuraju and Becker, 2003), which increase enzymatic antioxidants (Oseni and Idowu, 2014). Reducing TBARS concentration, as a product of lipid peroxidation, may be related to a decreased fat deposition by reducing the malate dehydrogenase and lipoprotein lipase activities, or increasing the hormone-sensitive lipase activity in the adipose tissue (Lu et al., 2007).

Generally, the MO leaves has anti-tumor and antinflammatory properties (Paul et al., 2018). Concerning the observed improvement in immunity of rabbits treated with MODLP, similar results were reported on growing rabbits fed MO leaf meal under moderate heat stress (El-Gindy et al., 2017), broilers fed MO leaves (Olugbemi et al., 2010) and mice orally treated with MO leaves methanolic extract (Sudha et al., 2010). 
Table (9): Effect Moringa oleifera dry leaves powder on antioxidant and immunity status of NZW growing rabbits.

\begin{tabular}{|c|c|c|c|c|c|c|}
\hline \multirow[b]{2}{*}{ Item } & \multirow[b]{2}{*}{$\begin{array}{c}\text { Control } \\
\text { (G1) }\end{array}$} & \multicolumn{3}{|c|}{ Moringa oleifera dry leaves powder level } & \multirow[b]{2}{*}{ SEM } & \multirow[b]{2}{*}{$\begin{array}{l}\mathrm{P}- \\
\text { value }\end{array}$} \\
\hline & & $\begin{array}{c}\mathrm{G} 2 \\
(100 \mathrm{mg} / \mathrm{kg} \\
\text { diet })\end{array}$ & $\begin{array}{c}\mathrm{G} 3 \\
(200 \mathrm{mg} / \mathrm{kg} \\
\text { diet })\end{array}$ & $\begin{array}{c}\mathrm{G} 4 \\
(300 \mathrm{mg} / \mathrm{kg} \\
\text { diet })\end{array}$ & & \\
\hline \multicolumn{7}{|l|}{ Antioxidant status: } \\
\hline TAC (mmol/l) & $1.97^{\mathrm{c}}$ & $2.18^{\mathrm{b}}$ & $2.31^{\mathrm{a}}$ & $2.12^{\mathrm{b}}$ & 0.023 & 0.0001 \\
\hline TBARS (nmol/ml) & $1.23^{\mathrm{a}}$ & $1.12^{\mathrm{b}}$ & $1.01^{\mathrm{c}}$ & $1.13^{\mathrm{b}}$ & 0.024 & 0.0001 \\
\hline \multicolumn{7}{|l|}{ Immunity status: } \\
\hline Antibody titer & $5.31^{\mathrm{d}}$ & $5.56^{\mathrm{c}}$ & $6.02^{\mathrm{a}}$ & $5.66^{\mathrm{b}}$ & 0.031 & 0.0001 \\
\hline Lysozyme (ug/mL) & $103.80^{\mathrm{b}}$ & $111.60^{\mathrm{ab}}$ & $118.40^{\mathrm{a}}$ & $108.60^{\mathrm{b}}$ & 2.820 & 0.0155 \\
\hline
\end{tabular}

Carcass traits: Results showed that net carcass weight percentage and dressing rate in all treatment groups, and spleen weight percentage in G3 and G4 significantly $(\mathrm{P}<0.05)$ increased compared with control group. However, heart and tests weight percentages in G4, and abdominal fat weight percentage in $\mathrm{G} 3$, significantly $(\mathrm{P}<0.05)$ decreased as compared to other groups. Other carcass traits were not affected by MODLP treatment (Table 10).

Table (10): Effect of Moringa oleifera dry leaves powder on carcass traits of growing rabbits.

\begin{tabular}{|c|c|c|c|c|c|c|}
\hline \multirow[b]{2}{*}{ Item } & \multirow[b]{2}{*}{$\begin{array}{c}\text { Control } \\
\text { (G1) }\end{array}$} & \multicolumn{3}{|c|}{ Moringa oleifera dry leaves powder level } & \multirow[b]{2}{*}{ SEM } & \multirow[b]{2}{*}{ P-value } \\
\hline & & $\begin{array}{l}\mathrm{G} 2 \\
(100 \mathrm{mg} / \mathrm{kg} \\
\text { diet) }\end{array}$ & $\begin{array}{c}\text { G3 } \\
(200 \mathrm{mg} / \mathrm{kg} \\
\text { diet })\end{array}$ & $\begin{array}{c}\mathrm{G} 4 \\
(300 \mathrm{mg} / \mathrm{kg} \\
\text { diet) }\end{array}$ & & \\
\hline Pre-slaughter weight (g) & 2093.00 & 2155.20 & 2193.00 & 2184.60 & - & - \\
\hline Net carcass weight $(\%)$ & $51.26^{\mathrm{c}}$ & $53.36^{\mathrm{b}}$ & $54.62^{\mathrm{a}}$ & $53.55^{\mathrm{b}}$ & 0.076 & 0.0001 \\
\hline \multicolumn{7}{|l|}{ Weight of edible offal's } \\
\hline Head weight $(\%)$ & 5.14 & 5.03 & 5.04 & 4.95 & 0.121 & 0.7529 \\
\hline Liver weight $(\%)$ & 2.59 & 2.54 & 2.53 & 2.50 & 0.100 & 0.9364 \\
\hline Kidney weight (\%) & 0.58 & 0.57 & 0.58 & 0.56 & 0.075 & 0.9960 \\
\hline Heart weight $(\%)$ & $0.29^{\mathrm{a}}$ & $0.28^{\mathrm{ab}}$ & $0.28^{\mathrm{ab}}$ & $0.27^{b}$ & 0.003 & 0.0010 \\
\hline Spleen weight $(\%)$ & $0.04^{\mathrm{b}}$ & $0.04^{\mathrm{b}}$ & $0.05^{\mathrm{a}}$ & $0.05^{\mathrm{a}}$ & 0.001 & 0.0009 \\
\hline Testes weight $(\%)$ & $0.18^{\mathrm{a}}$ & $0.18^{\mathrm{a}}$ & $0.18^{\mathrm{a}}$ & $0.17^{\mathrm{b}}$ & 0.001 & 0.0129 \\
\hline Total edible offal's (\%) & 8.82 & 8.64 & 8.66 & 8.50 & 0.244 & 0.8453 \\
\hline Dressing $(\%)^{*}$ & $60.08^{c}$ & $62.02^{\mathrm{a}}$ & $63.30^{\mathrm{a}}$ & $62.05^{\mathrm{b}}$ & 0.280 & 0.0001 \\
\hline \multicolumn{7}{|l|}{ Weight of in-edible offal's } \\
\hline Lung weight (\%) & 0.90 & 0.87 & 0.87 & 0.86 & 0.073 & 0.8934 \\
\hline $\begin{array}{l}\text { Digestive tract weight } \\
(\%)\end{array}$ & 0.181 & 0.178 & 0.177 & 0.175 & 0.002 & 0.2447 \\
\hline Skin $(\%)$ & 18.48 & 18.04 & 17.97 & 17.73 & 0.255 & 0.2557 \\
\hline Blood (\%) & 2.87 & 2.79 & 2.77 & 2.76 & 0.171 & 0.9734 \\
\hline $\begin{array}{l}\text { Total in-edible offal's } \\
(\%)\end{array}$ & 40.367 & 39.542 & 39.369 & 38.871 & 0.396 & 0.0990 \\
\hline Abdominal fat $(\%)$ & $0.86^{\mathrm{a}}$ & $0.83^{\mathrm{ab}}$ & $0.78^{b}$ & $0.82^{\mathrm{ab}}$ & 0.008 & 0.0001 \\
\hline
\end{tabular}


The important effect of pre-slaughter body weight on carcass characteristics. Therefore, as expected, carcass traits showed similar trend in treated groups compared with the control (Szendro et al., 1995). In accordance with the present results, Aljohani and Abduljawad (2018) showed that dietary MO supplementation improve carcass traits of growing rabbits. Also, El-Kholy et al. (2018a) found that Addition of aqueous extract of MO leaves in drinking water improved carcass characteristic of growing rabbits. Moreover, El-Badawi et al. (2014) concluded that inclusion of MODLP as a natural feed additive is highly recommended to enhance carcass dressing percentage of growing rabbits.

Such results might lead to support our suggestion that, addition of MODLP could boost feed utilization of rabbits by increasing the absorptive area of the small intestine in an action most likely to that of bacterial probiotics (El-Badawi et al., 2014). The observed decrease in abdominal fat percentages, especially in G3 is in association with reducing serum lipid profile as affected by MODLP treatment. In this respect, Toghyani et al. (2011) showed that MO supplementation was found to improve in beneficial bacteria (Lactobacillus) that reduce acetyl-CoA carboxylase activity, which is the rate-limiting enzyme in fatty acids synthesis.

Regard to the chemical composition the growing rabbit's meat, MODLP had insignificant $(\mathrm{P}>0.05)$ effect on percentage of crude protein, ether extract, ash and water content (Table 11). Although the powerful effects of MO on improving the meat quality properties as mentioned by (Kahraman et al., 2015), the insignificant effect of MO on meat composition in our study was reported by Helal et al. (2017) on growing rabbits. Generally, MODLP had no adverse effects on the carcass traits or meat quality of growing rabbits.

Table (11): Effect of Moringa oleifera dry leaves powder on meat composition of NZW growing rabbits.

\begin{tabular}{|c|c|c|c|c|c|c|}
\hline \multirow[b]{2}{*}{ Item } & \multirow[b]{2}{*}{$\begin{array}{c}\text { Control } \\
\text { (G1) }\end{array}$} & \multicolumn{3}{|c|}{ Moringa oleifera dry leaves powder level } & \multirow[b]{2}{*}{ SEM } & \multirow[b]{2}{*}{$\begin{array}{l}\mathrm{P}- \\
\text { value }\end{array}$} \\
\hline & & $\begin{array}{l}\text { G2 } \\
(100 \mathrm{mg} / \mathrm{kg} \\
\text { diet) }\end{array}$ & $\begin{array}{c}\mathrm{G} 3 \\
(200 \mathrm{mg} / \mathrm{kg} \\
\text { diet) }\end{array}$ & $\begin{array}{c}\mathrm{G} 4 \\
(300 \mathrm{mg} / \mathrm{kg} \\
\text { diet })\end{array}$ & & \\
\hline Water content & 70.59 & 70.55 & 70.50 & 70.60 & 0.981 & 0.9998 \\
\hline Crude protein & 20.70 & 20.65 & 20.72 & 20.66 & 0.989 & 0.9999 \\
\hline Crude fat & 7.100 & 7.18 & 7.12 & 7.10 & 0.079 & 0.8696 \\
\hline Ash & 1.61 & 1.62 & 1.66 & 1.63 & 0.021 & 0.3530 \\
\hline
\end{tabular}

\section{CONCLUSION}

Results of the current study suggest that dietary addition of Moringa olefira dried leaves up to 200 $\mathrm{mg} / \mathrm{kg}$ diet, as a natural antioxidant and antibacterial agent, could be better strategy to improve productive performance, bacterial loading, haematological and biochemical blood constituents, immune response and endogenous antioxidant status of growing rabbits under heat stress condition.

\section{REFERENCES}

Abalaka, M.E., S.Y. Daniyan, S.B. Oyeleke and S. O. Adeyemo (2012). The antibacterial evaluation of Moringa oleifera leaf extracts on selected bacterial pathogens. J. Microbiol. Res. 2:1-4.

Abubakar, M.U., A.U. Ibrahim, A.S. Yusuf and N.A. Muhammad (2015). Growth performance, carcass and organ characteristics of growing rabbits fed graded levels of Moringa oleifera leaf meal in diets. BAJOPAS. 8:7-9.

Achikanu, C.E., P.E. Eze-Steven, C.M. Ude and O.C. Ugwuokolie (2013). Determination of the vitamin and mineral composition of common leafy vegetables in South Eastern Nigeria. IJCMAS, 2:347-353.

Addass, P.A., A. Midau and D.M. Babale (2010). Hemato-biochemical findings of indigenous goats in Mubi, Adamawa State, Nigeria. J. Agric. Social Sci. 6:14-16. 
Aljohani, N.E. and S.H. Abduljawad (2018). Efficacy of Moringa oleifera leaf supplementation for enhanced growth performance, haematology and serum biochemistry of rabbits. Food and Nutrition Sciences, 9: 1285-1298.

AOAC. (2012). Official Methods of Analysis, $19^{\text {th }}$ ed. Association of Official Analytical Chemists, Washington, DC, USA.

Babeker, E.A. and Y.M. Abdalbagi (2015). Effect of feeding different levels of Moringa oleifera leaves on performance, hematological, biochemical and some physiological parameters of Sudan Nubian goats. Online J. Anim. Feed Res. 2:50-61.

Bukar, A., A. Uba and T. Oyeyi (2010) .Antimicrobial profile of Moringa oleifera Lam. extracts against some, food-borne microorganisms. BAJOPAS. 3:43-48.

Caceres, A., O. Cabrera and O. Morales (1991). Pharmacological Properties of Moringa oleifera: Preliminary Screening for Antimicrobial Activity. J. Ethnopharmacology. 33: 213-216.

Collins, C.H., P.H. Lyne and J.M. Grange (1995). Collins and Lyne's Microbiological Methods. Butterworth heinemann Ltd., Oxford.

Duncan, D.B. (1955). Multiple range and Multiple F test. Biometrics.11:1-42.

El-Badawi, A.Y., H.A.A. Omer, A.A. Abedo and M.HM. Yacout (2014). Response of growing New Zealand White rabbits to rations supplemented with different levels of Moringa oleifera dry leaves. Global Vet., 4: 573-582.

El-Gindy, Y. M., H.S. Zeweil and M. Hamad (2017). Effects of Moringa leaf as a natural antioxidant on growth performance, blood lipid profiles and immune response of rabbits under moderate heat stress. Egypt. Poult. Sci. 37:333-344.

El-Kholy, K.H., A.B. Safaa, W.A. Morsy, K. Abdel-Maboud, M.I. Seif-Elnaser and N. Gh. Mervat. (2018a). Effect of aqueous extract of Moringa oleifera leaves on some production performance and microbial gcology of the gastrointestinal tract in growing rabbits. Pak. J. Nutr. 17: 1-7.

1-Kholy, K.H., A.B. Safaa, W.A. Morsy, K. Abdel-Maboud, M.I. Seif-Elnaser and N. Gh. Mervat. (2018b). Hematological and serum biochemical responses of growing rabbits to aqueous extract of Moringa Oleifera leaves in drinking water. J. Anim and Poul Prod., Mansoura Univ. 9:17 - 22.

Etchu, A.K., B.L. Tientcheu, M.O.S. Ghomsi, J.T. Enow, N.M. Tuedom and G. Enamou (2017). Effect of Moringa Oleifera leaf meal (Molm) on the growth, carcass, heamatology and biochemical parameters of Rabbits. SOJ Vet Sci. 3:1-5.

Ewuola, E.O., O.A. Sokunbi, K.M. Sanni, O.M. Oyedemi and T.T. Lawal (2015). Hematological and serum biochemical responses of rabbit does to crude Moringa oleifera leaf extract at gestation and lactation. Trop. Anim. Health Prod. 47: 637-642.

Faye, B., B, Bucheton and A.L. Banuls (2010). Prevalence of Leishmania Infantum in a Rural Area of Senegal: Analysis of Risk Factors Involved in Transmission to Humans. Trans. R. Soc. Trop. Med. Hyg. 105: 333-340.

Giannenas, I., I.S. Pappas, S. Mavridis, G. Kontopidis, J. Skoufos and I Kyriazakis (2010). Performance and antioxidant status of broiler chickens supplemented with dried mushrooms (Agaricus bisporus) in their diet. Poult. Sci. 89: 303- 311.

Godstime, O.C., O.E. Felix, J.O. Augustina and E.O. Christopher (2014). Mechanisms of Antimicrobial Actions of Phytochemicals against Enteric Pathogens-A Review. Journal of Pharmaceutical, Chemical and Biological Sciences. 2:77-85.

Guyton, A.C. and J.E. Hall (2000). Textbook of medical physiology. $12^{\text {th }}$ Edn., Philadelphia. Saunders Company.

Harborne, J.B. (1973). Phytochemical Methods: A guide to modern techniques of plant analysis. Chapman and Hall, New York. 2:88-185

Hassan, H.M.A., M.M. El-Moniary, Y, Hamouda, F.E. Eman, W.Y. Amani and A.A. Nafisa (2016). Effect of different levels of Moringa oleifera leaves meal on productive performance, carcass characteristics and some blood parameters of broiler chicks reared under heat stress conditions. Asian J. Anim. Vet. Adv. 11: 60-66. 


\section{Khalil et al}

Hassarajani, S., T.D. Souza, S.A. Mengi and S. Chattopadhayay (2007). Efficacy study of the bioactive fraction (F-3) of Acoruscalamus in hyperlipidemia. Indian J. Pharmacol. 39:196-200.

Helal, F.I.S., A.Y. El-Badawi, I. El-Wardany, N.G.M. Ali and O.M. Aboelazab (2017). Effect of dietary moringa (Moringa oleifera) and rosemary (Rosmarinus officinalis) leaves or their mixture on productive performance, carcass characteristics and antioxidant enzymes of rabbits reared under heat stress conditions. Agricultural Engineering International: CIGR Journal, Special issue: 184-192.

Kahraman, T., G. Issa, E.B. Bingol, B.B. Kahraman and E. Dumen (2015). Effect of rosemary essential oil and modified-atmosphere packaging (MAP) on meat quality and survival of pathogens in poultry fillets. Braz. J. Microbiol. 46:591-599.

Khalil, F. and F.M.M. korni (2017). Evaluation of Moringa oleifera leaves and their aqueous extract in improving growth, immunity and mitigating effect of stress on common carp (Cyprinus Carpio) fingerlings. Turkish J Aqua Sci.32: 170-177.

Kim, H.U., J.M. Goepfert (1971). Enumeration and identification of Bacillus cereus in foods I. 24-hour presumptive test medium. Applied Microbiol. 22: 581-587.

Kumaran, A. and R. J. Karunakaran (2007). In vitro antioxidant activities of methanol extracts of phyllantus species from India. Lebens -Wiss technologie. 40: 344-352.

Lu, L., X.G. Luo, C. Ji, B. Liu and S. X. Yu (2007). Effect of manganese supplementation and source on carcass traits, meat quality, and lipid oxidation in broilers. J. Anim. Sci. 85:812-822.

Luqman, S., S. Srivastava, R. Kumar, A.K. Maurya and D. Chanda (2011). Experimental assessment of Moringa oleifera leaf and fruit for its anti-stress, antioxidant and scavenging potential using in vitro and in vivo assays. Evidence-Based Complement. Altern. Med. Article ID 519084, 1-11.

Malliga, E., M.S. Dhanarajan, A. Rajalakshmi, A. Jayachitra, M. Pardhasaradhi and B. Narasimharao (2014). Analysis of phytochemicals, antibacterial and antioxidant activities of Moringa oleifera lam. leaf extract- an in vitro study. Int. J. Drug Dev. Res. 6:173-180.

Marai, I.F.M., M.S. Ayyat and U.M. Abd El-Monem (2001). Growth performance and reproductive traits at first parity of New Zealand White female rabbits as affected by heat stress and its alleviation under Egyptian conditions. Trop Anim Health Prod. 33:451-462.

Marai, I.F.M., A.A.M. Haeeb and A.E. Gad (2002). Rabbits productive, reproductive and physiological performance traits as affected by heat stress a review. Livest Sci, (Netherlands). 78: 71-90.

Marai, I.F.M., A.A.M. Haeeb and A.E. Gad (2007). Biological functions in young pregnant rabbit does as affected by heat stress and lighting regime under sub-tropical conditions of Egypt. Trop. Subtrop. Agroecosyst. 7: 165- 176.

Mbikay, M. (2012). Therapeutic potential of Moringa oleifera leaves in chronic hyperglycemia and dyslipidemia: A review. Frontier Phamacol. 3:1-12.

McDonald, S., P.D. Prenzler, M. Autolovich and K. Robards (2001). Phenolic content and antioxidant activity of olive extracts. Food Chem.73: 73-84.

Musa, A.S.I., D.I. Jibrin, A.A. Hassan and A. Yakubu (2014). Effects of oral administration of Moringa oleifera seed on blood chemistry and reproductive performance of female rabbits. Int. J. Agric. Sci. and Vet. Med. 2: 18-21.

Nelson, N.A., N. Lakshmanan and S.J. Lamont (1995). Sheep red blood cell and Brucellaabortus antibody responses in chickens selected for multitraitimmuno competence. Poult. Sci., 74: 1603-1609.

NRC. (1977). Nutrient requirements of rabbits, $2^{\text {nd }}$ Revised edn. National Academy of Sciences, Washington, DC.

Ojo, O.A. and S.A. Adetoyi (2017). Effect of Moringa oleifera leaf extract on the haematological and serum biochemistry of rabbits reared in a semi-humid environment. Afr. J. Biotechnol. 16:1386-1390.

Okab, A.B., S.G. El-Banna and A.A. Koriem (2008). Influence of environmental temperatures on some physiological and biochemical parameters of New-Zealand rabbit males. Slovak J. Anim. Sci. 41:12 19. 
Okwari, O.A., K, Dasofunjo, A,A, Asuk, E.A. Alagwu and C.M. Mokwe (2013). Antihypercholesterolemic and hepatoprotective effect of aqueous leaf extract of Moringa oleifera in Rats fed with thermoxidized palm oil diet. IOSR J. Pharm. Biol. Sci. 8:57-62.

Olugbemi, T.S., S.K. Mutayoba and F.P. Lekule (2010). Effect of moringa (Moringa oleifera) inclusion in cassava based diets to broiler chickens. In International J. Poultr. Sci. 9: 363-367.

Oseni, O.A. and A.S.K. Idowu (2014). Inhibitory activity of aqueous extracts of horseradiash Moringa oleifera (lam) and nutmeg Myristica fragrans (houtt) on oxidative stress in alloxan induced diabetic male Wistar Albino rats. Am J Biochem Biotechnol. 4: 64-75.

Osman, H.M., M.E. Shayoub and E.M. Babiker (2012). The effect of Moringa oleifera leaves on blood parameters and body weights of Albino rats and rabbits. Jordan J. of Biological Sci. 5:147-150.

Otitoju, O., J.U. Nwamarah, G.T.O. Otitoju, A.U. Okorie, C, Stevens and K.P.X. Baiyeri (2012). Effect of Moringa oleifera aqueous leaf extract on some haematological indices in Wistar rats. J. Nat. Sci. Res. 4: 74-77.

Oyedemi, S.O., E.A. Adewusi, O.A. Aiyegoro and D.A. Akinpelu (2011). Antidiabetic and haematological effect of aqueous extract of stem bark of Afzelia africana (Smith) on streptozotocin induced diabetic Wistar rats. Asian Pac. J. Trop. Biomed. 1:353-358.

Paul, T.K., A.S. Yousuf, T. Moniruzzaman, R. Asaduzzaman, H. Anowarul and H.S. Mahmudul (2018). Water supplementation of Moringa oleifera as a substitute for antibiotics on performance and blood parameters of broiler chickens. J Bangladesh Agril Univ. 16: 266-270.

Provan, D., C.R.J. Singer, T. Baglin and L. Lilleman (2004). Oxford Handbook of Clinical Hematology. 2th Edition, Oxford University Press, USA.

SAS. (2002). SAS Institute Inc. SAS User's Guide, Statistics. Cary, NC.

Schultz, L.A. (1987). Methods in Clinical Chemistry. The C.V. Mosby Co. St Louis. 742-746.

Serem, J.K., R.G. Wahome, D.W. Gakuya, S.G. Kiama, G.C. Gitao and D.W. Onyango (2017). Growth performance, feed conversion efficiency and blood characteristics of growing pigs fed on different levels of Moringa oleifera leaf meal. J. Vet. Med. Anim. Health. 9:327-333.

Siddhuraju, P. and K, Becker (2003). Antioxidant properties of various solvent extracts of total phenolic constituents from three different agroclimatic origins of drumstick tree (Moringa oleifera Lam.) leaves. J. Agric. Food Chemist. 51: 2144-2155.

Sudha, P., S.M. Asdaq, S.S., Dhaming and G.K. Chandrakala (2010). Immu-nomodulatory activity of methanolic le extract of Moringa oleifera in animals. Ind. J. Physiol. Pharmacol. 54: 133-140.

Surai, P.F. (2002). Natural Antioxidants in Avian Nutrition and Reproduction. Nottingham University Press, Nottingham.

Szendro, Z.S., I. Randai, E. Birone-Nemeth, R. Romvari and G. Milists (1995). Effect of live weight on the carcass traits of pennon white rabbits. Proceedings of the 3rd International Symposium on Animal Science Days, September 26-29, Bled, Slovenia.

Terzungwe, A., H.A. Adakole and K.I. Lois (2013). Physiological responses of rabbits fed graded levels of Moringa oleifera leaf meal (MOLM): Some aspects of haematology and serum biochemistry. Arch. Appl. Sci. Res. 5:172-176.

Toghyani, M., M, Toghyani and S.A. Tabeidian (2011). Effect of probiotic and prebiotic as antibiotic growth promoter substitutions on productive and carcass traits of broiler chicks. Proceedings of the International Conference on Food Engineering and Biotechnology, May 7-9 Bangkok, Thailand, pp: 82-86.

Tuorkey, M.J. (2016). Effects of Moringa oleifera aqueous leaf extract in alloxan induced diabetic mice Interv. Med. Appl. Sci. 8:109-117.

Villalobos, O., O. Guillen and J, Garcia (2008). Effect of cage density on growth and carcass performance of fattening rabbits under tropical heat stress conditions. World Rabbit Sci.16: 89-97.

Warner, A.C.I. (1964). Production of Volatile Fatty Acid in the Rumen. 1: Method of Measurements. Nutr Abstr Rev. 34:339-410. 


\title{
Khalil et al
}

Wegmann, T.G. and O.A. Smithies (1966). Simple hemagglutination system requiring small amount of red cells and antibodies. Transfusion. 6: 67-73.

تأثير اضافة اوراق المورينجا أوليفيرا على الاداء الانتاجى، صفات الأبيحة، خصائص الام الهيماتو-بيوكيميائية،

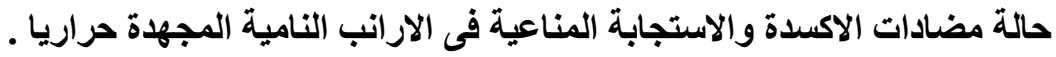

\author{
وائل احمد خليل، رحاب فوزى صديق عبد الفتاح اسماعيل1 و ابراهيم طلعت الرطل2 \\ اقسم انتاج العيوان - كلية النزراعة جامعة الدنصورة- مصرئ

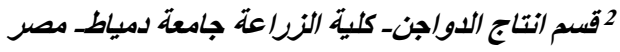

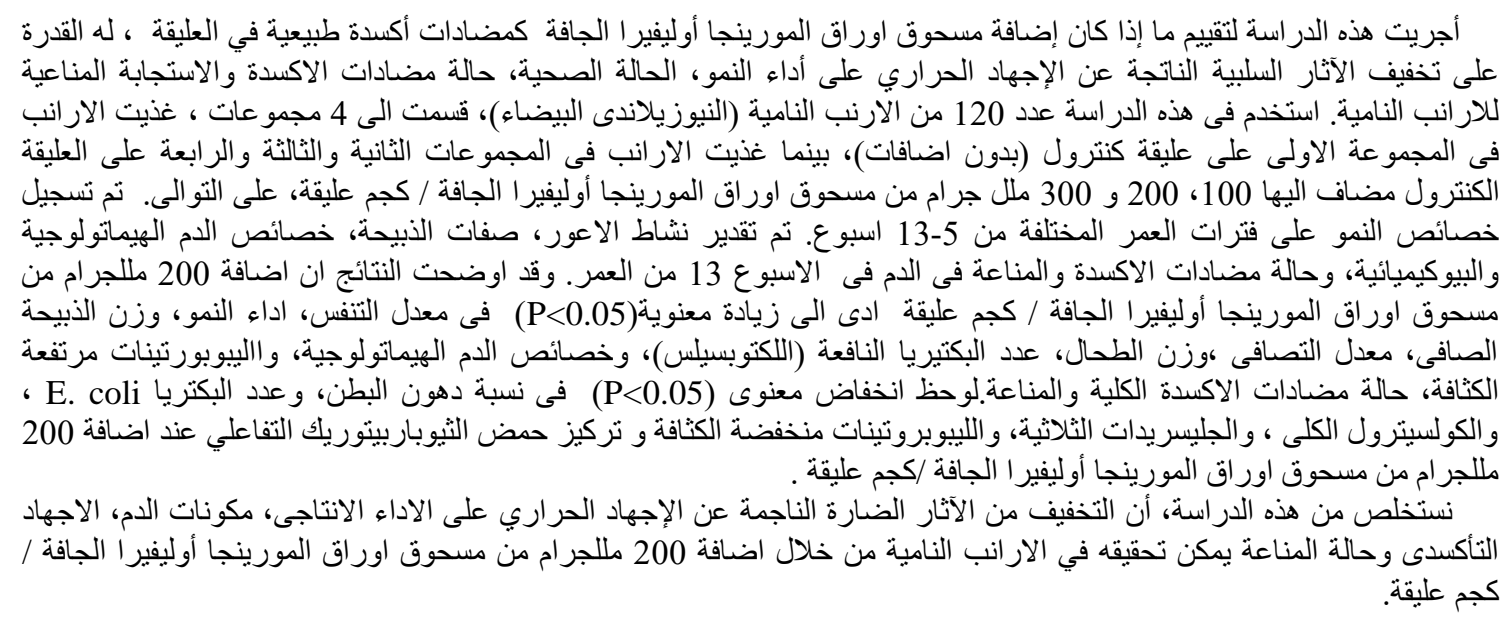

